\title{
Research Regarding the Evolution of Freshness State of European Catfish Meat Stored in Refrigerated Form
}

\author{
Emanuel MĂGDICI*, Cătălin E. NISTOR, Ionuț B. PAGU, Mădălina I. IORDACHE, \\ Aida ALBU, Gabriel V. HOHA, Benone PĂSĂRIN \\ U.S.A.M.V. Iaşi, Romania \\ *Corresponding author, email: emanuel.magdici@yahoo.com
}

Bulletin UASVM Animal Science and Biotechnologies 72(1) / 2015

Print ISSN 1843-5262; Electronic ISSN 1843-536X

DOI:10.15835/buasvmcn-asb:10593

\begin{abstract}
European catfish (Silurus glanis) the biggest fresh water fish from Europe is a breed that present a great interest among the fish breeders, due to its good growing rhythm, as well as among consumers, due to its remarkable sensorial properties. As in the case of other fish breeds, the main selling way is under refrigerated form. The current study aims to observe the qualitative modifications, which took place in refrigerated meat of Silurus glanis breed for a period of 16 days. Samples were evaluated by analyzing the sensorial features, $\mathrm{pH}$ and $\mathrm{NH}_{3}$, during 7 intervals corresponding to days $0,2,4,8,12,14$ and 16 of storage. Sensorial analysis qualified samples as being "very good" till day 4, "good" till day 8, "satisfactory" day 12, "inappropriate" day 14 and altered at the end of storage period. The $\mathrm{pH}$ recorded a value of 6.98 after slaughtering, constantly decreasing till day 4, so that in day 16 the obtained value to be 7.32 which show an inappropriate product for selling and consumption. Values obtained for $\mathrm{NH}_{3}$, present a close correlation with the other indicators utilized to evaluate the freshness state of fish meat, ranking the products as fresh till day 12 (27.10) and inappropriate for consumption starting with day 14.
\end{abstract}

Keywords: European catfish, refrigeration, freshness state, storage

\section{INTRODUCTION}

Fish meat has remarkable sensorial qualities and a very good nutritive value, its main lack being the weak state of preservation (Usturoi et al., 2009). Refrigeration in chilled airflow is one of the most frequent methods for preservation utilized in fish processing (Ionescu et al., 2006). Optimal interval for storage of preserved fish meat through this method could vary function of several parameters, the most important ones being technological and biological parameters (Iurca, 2008).

European catfish (Silurus glanis), the main representative for Siluridae family on European continent (Tekelioğlu, 2005), is a breed with an ascendant rearing trend in Europe from 350 tons/ year in 1993, at around 1200 tons/year nowadays (FAO, 2012). This evolution could be explained by the following main factors: a very tasty meat, very appreciated by the consumers especially in Eastern Europe and Asia (Küçükgülmez et al., 2010), is a useful fish in fisheries exploitations, where being reared in poly-culture with other breeds assures a good health state of biocenosis from which belongs (Alp et al., 2004; Brzuska and Adamak, 1999) and at last but not least due to its impressive dimensions and to the fight oppose during drill is well appreciated in fishing competitions in countries like Spain, Holland, France and Italy (Benigno, 2001). Also, the growing rhythm is very good, tegument without scales, white meat, without bones, with a lipid content between 4 and $8 \%$. All those elements are a good reason to allow a special attention to these breeds. The current research aims to establish the optimal storage period of refrigerated meat gathered from 
European catfish (Silurus glanis), processed as skinless filets.

\section{MATERIALS AND METHODS}

Samples' preparation and processing.

The studied breed is represented by European catfish (Silurus glanis), with an average of body mass around the value of $2000 \mathrm{~g}$, gathered from a fishery farm from Iaşi County, where was reared in soil ponds in poly-culture with different breeds belonging to Cyprinidae family. Biological material was transported alive at Aquaculture Laboratory from UASVM Iaşi where was slaughtered. The studied samples were represented by 6 European catfish individuals, which were evaluated from gravimetric point of view and after that were beheaded with a profiled cut, eviscerated and filleted. Also, the obtained filets were skinned. For preservation through refrigeration in chilled air flow, the obtained product was stored in polystyrene casseroles with lid, having inside adsorbent material for retention of eventually resulted liquids. Storage temperature was $+2^{\circ} \mathrm{C}$, samples being separately packed for each set of analysis to avoid disconnection of refrigeration cycle. Freshness state of filets was evaluated during 16 days (days $0,2,4,8,12,14,16$ ), making sensorial physical and chemical analysis.

Sensorial analysis. Sensorial evaluation was realized by a team forms by seven members, experts in fish meat processing and checking. Sensorial analysis was realized into a special designed room, which respects all the technical conditions imposed for this type of analyze. Using a modern working method (Banu et al., 2007), each member of analyzing committee received a coded sample, for each storage period. In according with the presentation way of samples, those ones are classified in category of cut products, shape being a rectangular one and average weight is $20 \mathrm{~g} /$ piece. Sensorial evaluation of samples was made using analytical appreciation method for quality by scoring, using a 0-5 points appreciation scale for meat products (Banu et al., 2007). In according with the used system of evaluation, for each analyzed feature was given a score between 5 and 0 , where 5 indicates the optimal parameters for the analyzed sensorial character, in according with the product standard and following a descendant trend, obtaining of minimum score, 0 , indicates inappropriate features, for each type of sensorial character. As sensorial features there were analyzed general aspect, color, smell and texture. Calculus utilized for quantitative evaluation through sensorial features is based on formula:

$$
\text { Pmp }=\operatorname{Pm} * \mathrm{f}_{\mathrm{i}} * \mathrm{f}_{\mathrm{t}}
$$

where:

Pmp is the mean ponderate score;

$\mathrm{Pm}$ is the mean score, which represents the arithmetic mean of evaluation results by points of a sensorial feature by a group of testers;

$f_{i}$ is importance factor which indicates the participation rate of each sensorial feature to product quality;

$f_{t}$ is transformation factor utilized for changing the $0-5$ points scale into 20 points scale, to establish the product quality (in current case the value of transformation factor is 4).

Based on the obtained results, at the end of sensorial evaluation, was calculated the total mean score (Pmt) by summing the ponderate mean scores from all sensorial features. Values were interpreted based on score scale for qualitative evaluation.

Physical analysis. Evaluation of alteration level of studied samples was made through $\mathrm{pH}$

Tab. 1. Score scale for qualitative evaluation on a 0-20 points scale (after Banu et al., 2007).

\begin{tabular}{cc}
\hline Total mean score & Qualification \\
\hline $18.1-20$ & Very good \\
\hline $15.1-18$ & Good \\
\hline $11.1-15$ & Satisfactory \\
\hline $7.1-11$ & Inappropriate \\
\hline $0-7$ & Altered \\
\hline
\end{tabular}

and $\mathrm{NH}_{3}$ evaluation. Acidity of muscular tissue is appreciated by electrometric measurements, using $\mathrm{pH}$-meter. The $\mathrm{pH}$ was potentiometric determined on watery extract from fish meat. Preparation of sample implies the introduction into a $200 \mathrm{~cm}^{3}$ glass of $10 \mathrm{~g}$ of muscular tissue well minced and weighted with a precision of $0.01 \mathrm{~g}$. Is added $100 \mathrm{ml}$ distilled water and it is placed at room temperature for 10 minutes, stirring the content from time to time with a glass rod. In the obtained solution $\mathrm{pH}$ is determined using a pH-meter. Function of freshness state meat $\mathrm{pH}$ could be: between 7 and 7.3 (just after catching and slaughtering), 6.2 and 6.8 (for fresh fish) and 
6.8-7.5 (for altered fish) (Banu et al., 2004). The utilized $\mathrm{pH}$-meter in the current research was a HANNA INSTRUMENTS $98240 \mathrm{pH}$-oximeter with a self-adjustment function for $\mathrm{pH}$ value function of measuring temperature, calibration kit in 2 points (4.01 and $7.01 \mathrm{pH}$ ) (production 2006, pH measuring interval 4.0-19.99; $\mathrm{mV} \pm 400.00 \mathrm{mV}$; temperature $-10^{\circ} \mathrm{C}-+120^{\circ} \mathrm{C}$; resolution $0.01 \mathrm{pH}$ points; accuracy at $20^{\circ} \mathrm{C} \pm 0.01 \mathrm{pH}$; electrode $\mathrm{pH}$ amplified with an included temperature sensor; EEPROM and DIN connector).

$\mathrm{NH}_{3}$ represents a chemical parameter, which indicates, function of its concentration, if meat is suitable or inappropriate for human consumption. $\mathrm{NH}_{3}$ is determined using a weak base, capturing with vapors and catching into an acid solution. The utilized reagents for this analysis are: sulphuric acid $0.1 \mathrm{~N}$, burnt magnesium oxide, sodium hydroxide solution $0.1 \mathrm{~N}$, neutral paraffin oil and methyl red $0.2 \%$ alcoholic solution. Working way consists is a $0.01 \mathrm{~g}$ precision weighing of $10 \mathrm{~g}$ from prepared sample, well minced, which is introduced into a 750-1000 ml distillation flask with $250 \mathrm{ml}$ of distilled water and $1.2 \mathrm{~g}$ of magnesium oxide. To avoid foamy are added some drops of neutral paraffin oil. The flask is connected to a refrigerant with an extension tube, which must go till the bottom of a $300 \mathrm{ml}$ Erlenmayer glass. In Erlenmayer glass are introduced $15 \mathrm{ml} \mathrm{H}_{2} \mathrm{SO}_{4} 0.1$ $\mathrm{N}$, some drops of methyl red and distilled water in a sufficient quantity so the top of extension tube to be completed sunk in liquid. Distillation last for 40 minutes from which 10 minutes for reaching the boiling temperature. In the case of liquid discoloring in Erlenmayer glass, a measured volume of $\mathrm{H}_{2} \mathrm{SO}_{4} 0.1 \mathrm{~N}$ is added. After 40 minutes distillation is interrupted and the $\mathrm{H}_{2} \mathrm{SO}_{4}$ excess is subjected to titration with $\mathrm{NaOH} 0.1 \mathrm{~N}$ till transfer of indicator.

Calculus of $\mathrm{NH}_{3}$ is made with the following equation:

$\mathrm{NH}_{3}(\mathrm{mg} / 100 \mathrm{~g})=\frac{0,0017\left(\mathrm{~V}_{\mathrm{1}}-\mathrm{V}\right) 100}{\mathrm{~m}^{2}}=\frac{0,17\left(\mathrm{~V}_{1}-\mathrm{V}\right)}{\mathrm{m}^{2}}$ in which:

0.0017 is ammonium quantity, in g, corresponding to $1 \mathrm{ml}$ of $\mathrm{H}_{2} \mathrm{SO}_{4} 0.1 \mathrm{~N} ; \mathrm{V}_{1}$-quantity of $\mathrm{H}_{2} \mathrm{SO}_{4} 0,1 \mathrm{~N}$ introduced in Erlenmayer glass, in ml; V-quantity of $\mathrm{NaOH} 0.1 \mathrm{~N}$, utilized for titration, in $\mathrm{ml} ; \mathrm{m}$-mass of analyzed sample, in g.

Function of freshness state, $\mathrm{NH}_{3}$ could be between the following values: 13.6-27.1 for fresh fish, 27.2-30 for quite fresh fish, and $>30$ for altered fish (Banu et al., 2004).

Chemical analysis. An important role in establishing the shelf life time of a meat product rests to its lipids content. Generally, it's admissible that light fish could be preserved for a longer period compared to the fat ones, due to fat susceptibility to rancidity (Usturoi et al., 2009). Fat determination was made using by Soxhlet method and consisted the first applied analysis to studied samples, to establish a most exactly evaluation period of freshness state for European catfish meat. The method principle and working way applied in the current research are in according with the ones detailed by Banu et al. (2004).

For gravimetric determinations, in all working stages, were used: a Shimadzu UX4200H technical balance, with measuring interval 0.014200 g (production 2005, measuring units: g, $\mathrm{kg}$, ct, lb; precision-0.01 g, repeatability-0.01 g, linearity $0.02 \mathrm{~g}$, self-adjustment function and communication with PC via a RS232 serial port) and an analytical balance Denver Instruments Pinnacle 214, with measuring interval $0.1 \mathrm{mg}-210$ g (production 2004, measuring units: g, kg, mg, ct, lb; precision- $0.2 \mathrm{mg}$, repeatability- $0.1 \mathrm{mg}$, linearity $0.2 \mathrm{mg}$, self-adjustment function and communication with PC via a RS232 serial port).

To avoid errors, samples and analysis were made in double trials.

\section{RESULTS AND DISCUSSION}

Fat content of European catfish fillets (Silurus glanis) obtained a mean of $3.40 \%( \pm 0.19)$, with a minimum of 3.2 and a maximum of 3.6 percents (Tab. 2). Variability of samples is situated under

Tab. 2. Lipids content at European catfish (Silurus glanis).

\begin{tabular}{lccccc}
\hline Specification & $\mathrm{n}$ & $\overline{\mathrm{x}}_{ \pm \mathrm{s}_{\overline{\mathrm{x}}}(\%)}$ & V\% & Min. (\%) & Max. (\%) \\
\hline Content in lipids (Silurus glanis) & 6 & $3.40 \pm 0.19$ & 7.25 & 3.20 & 3.60 \\
\hline
\end{tabular}


$10 \%$, which show the homogeneity of this character for the studied biological material.

In according with literature, fish with a lipids content under $4 \%$ are light fish (Ionescu et al., 2006; Usturoi et al., 2009), even if some researchers classify European catfish as a fat fish, with a fat content of over $8 \%$, (Bud and Mireşan, 2008; Kok et al., 2009). This thing is quite true because fat content for this breed is influenced by many factors such as: corporal mass, age, fishing season, feed type. Similar results, as the ones obtained in the current study, were reported, at the same value of corporal mass, also by Cirkovic (2012), Fauconneau and Laroche (1996), Hallier et al. (2006), Jankowska et al. (2006).

Taking into account the obtained data regarding fat content and correlated those information with the already existed ones in the literature regarding preservation of fish and fish products was establish an approximate period in which freshness state of European catfish fillets was evaluated.

Evolution of sensorial features. The results of qualitative modifications through recorded sensorial evaluation for European catfish fillets during storage in refrigerated way in chilled airflow are presented in Figure 1. Analyzed sensorial attributes were: general aspect, color, smell and texture. Each of those features were quoted on a scale from 0 to 5 , where value " 5 " indicates optimal parameters, in according with product standard, and "0", indicates inappropriate parameters from quality point of view.

In according with the obtained data for sensorial evaluation of European catfish fillets,

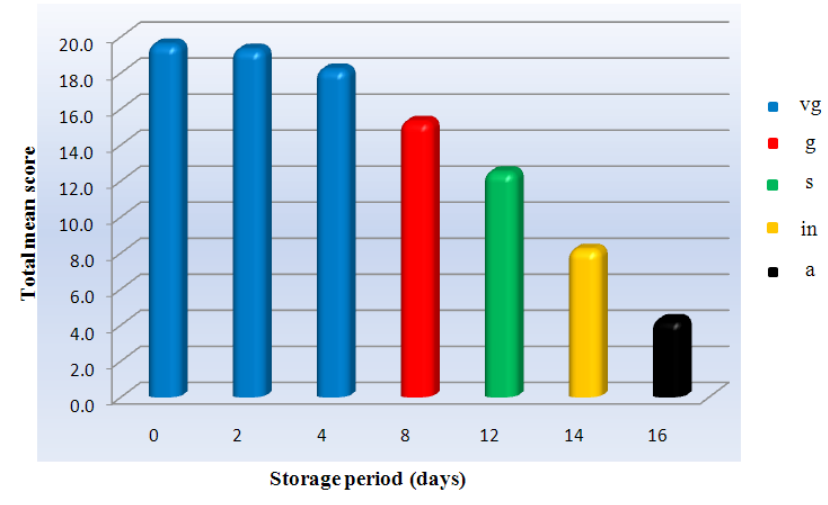

Fig. 1. Qualitative evolution of European catfish fillets (Silurus glanis) from sensorial point of view Note: vg=very good; g=good; s=satisfactory; in=inappropriate; $a=$ altered. in the first two analyzed intervals (day 0 and day 2) their quality was "very good" obtaining a score of 19.6 after slaughtering, respectively 19.3 in the second day of storage under refrigerated way. Also, in day 4 from starting of preservation process by refrigeration, evaluation team offered a score of 18.2, which qualify the analyzed samples as very good, being placed at the inferior limit for this qualification. Starting with day 8 evaluated samples were considered as being "good", having in view the obtained score of 15.3, score situated like in previous day at the inferior limit for its category. An important role was attributed to the modification of smell for analyzed samples, for which the majority of experts gave the lowest score being recorded a mean of 3.71 points. Tacking into account that both general aspect and also smell have a higher factor of importance in establishing the total mean score, this thing had a significant influence in establishing the quality of analyzed product. With a total mean score of 12.5 day 12 represented the last analyzed interval during refrigeration period in which samples are in according with product standard, those ones being suitable for consumption, but are not recommended to be sell. Starting with day 14 evaluated samples presented obvious defects for all the analyzed sensorial attributes, not fulfilling a compulsory condition in according with which a product could be sell only if mean score for each sensorial feature must have a minimum of 2.8 points. Total mean score for this interval is 8.2 points, which describe the analyzed samples as being inappropriate from qualitative point of view. Sensorial evaluation realized in the last day on storage under refrigerated way of European catfish fillets show the fact that those ones present obvious defects, specific to an altered product which cannot be consumed. At the end of refrigeration period meat color had a yellow nuance, acid smell, rotten, texture being flaccid, finger print maintaining for a long period. These aspects are underline also by the value of obtained total mean score, which had a value of 4.3 points. So, sensorial analysis show that fact that refrigerated European catfish fillets are in according with freshness state till day 12.

The $\mathrm{pH}$ modifications during storage. After slaughtering, $\mathrm{pH}$ for a mix obtained from muscular tissue of studied samples recorded the value of 6.98 and for days 2 and 4 to decrease till 6.33. Starting with day $8, \mathrm{pH}$ had constantly increased reaching 
the limit of 6.79 in day 14, value that indicate the fact that biological material is not optimal anymore from freshness point of view. Like in the case of sensorial analysis, $\mathrm{pH}$ value obtained in last day of fish storage under refrigeration modality (7.32) highlight which those one is altered, inappropriate for selling and consumption (Fig. 2).

Generally, $\mathrm{pH}$ values at different post-fishing periods are higher at mammals, due to formation of small amounts of lactic acid and due to a higher capacity of muscles buffering (Simeanu, 2012).

The $\mathrm{pH}$ initial decreasing could be explained that after fish slaughtering, by stopping the oxygen intake and sanguine circulation, muscular tissue goes to anaerobiosis, and glycolysis will transform in lactic acid, which is slowly accumulated in meat, aspect which influence meat acidity and implicit the value of obtained $\mathrm{pH}$. This will decrease more or less rapidly, till will reach a minimum value (5.5-6) (Nistor, 2013). At this value meat $\mathrm{pH}$, hydration capacity and water retention is minimal. Meat with a high $\mathrm{pH}$ (equal or superior to value 6 ) is more easily invaded by bacteria especially the putrefaction ones (Huss, 1995; Usturoi et al., 2009). Hossain et al. (2005), reported a similar evolution of $\mathrm{pH}$ during storage in refrigerated way, where initial pH at breed Pangasius sutchi was 7 after slaughtering, decreased till 5.98 at beginning at storage period, and after that recorded a constant increase till the end of those 14 days, when the experiment ended.

To evaluate the quality of fish products is important to analyze $\mathrm{pH}$ because meat acidity influences its quality under sensorial, hygienic and technological aspects (Huss, 1988). Those one determine and reflect the state of meat chemical

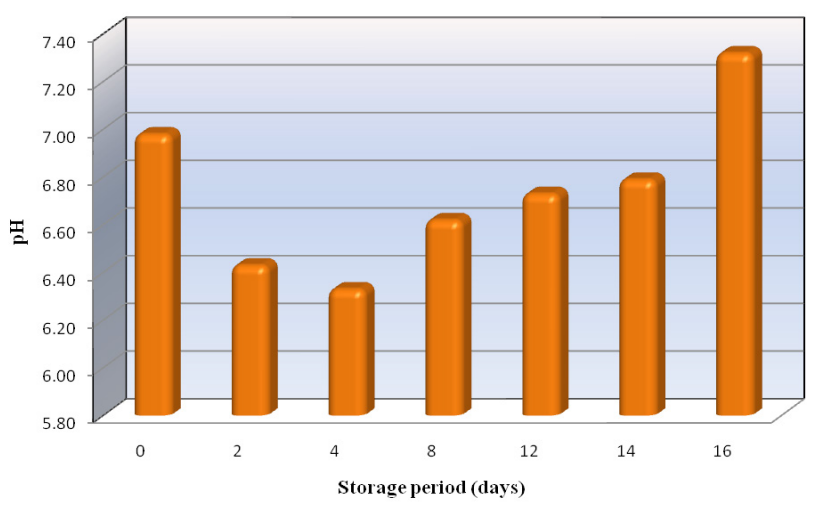

Fig. 2. The pH modifications at European catfish fillets (Silurus glanis) during storage. components and it is strongly correlated with color features. Acidity is in close and direct connection with other sensorial features (tenderness, consistency, flavor and taste) and influence water retain capacity as well as conservation period of meat (Savu, 2008)

$\mathrm{NH}_{3}$ evolution. Determination of $\mathrm{NH}_{3}$ represents a specific analysis for unprocessed fishing products, to establish their state of freshness. The values of those indicator recorded a constantly increase during storage of fish refrigerated in chilled air flow, minimum being recorded after slaughtering $(16.20 \mathrm{mg} / 100 \mathrm{~g})$, and maximum being in day $16(36.80 \mathrm{mg} / 100 \mathrm{~g})$, which indicated an altered meat (Fig. 3).

Even if $\mathrm{NH}_{3}$ value obtained in day 14 (32.34 $\mathrm{mg}$ ) is characteristic to altered fish in according with references cited after Banu (2004, 2008), exist journals which classify fish meat as being "relatively fresh" till value of $35 \mathrm{mg} \mathrm{NH}_{3} / 100 \mathrm{~g}$ analyzed product (Connel, 1995; Huss, 1988; Savu, 2008; Şindilar and Stratan, 1996), qualification recorded for this storage period also after $\mathrm{pH}$ analysis. Increasing of $\mathrm{NH}_{3}$ during prolongation of storage period for refrigerated fish in airflow, could be an effect of development of alteration microorganisms, especially of bacteria belonging to species Staphylococcus, Salmonella, Cl. Botulinum (Ihuahi et al., 2010; Ionescu et al., 2006).

The results obtained for $\mathrm{NH}_{3}$ could be considered a good indicator for freshness state of fish products, having in view the existent correlation between the results of those three indicators for meat products quality utilized in the current study.

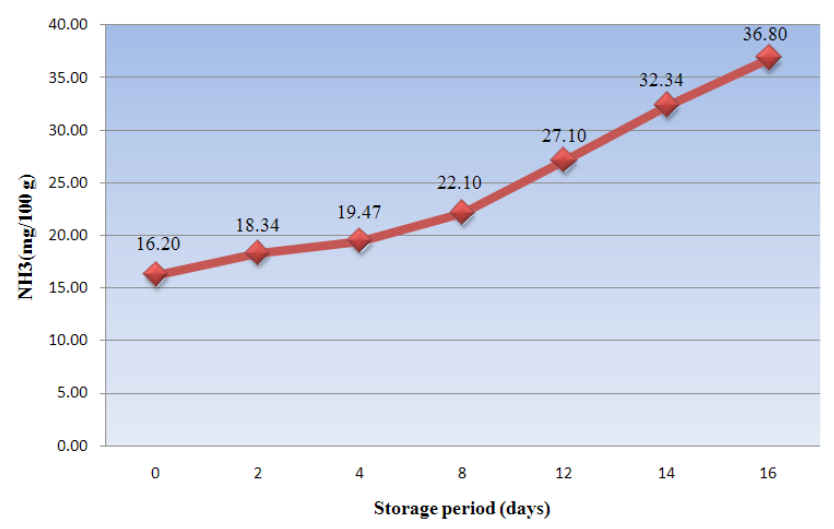

Fig. 3. Modification of $\mathrm{NH}_{3}$ during storage period for European catfish (Silurus glanis) refrigerated in airflow. 


\section{CONCLUSION}

The current study demonstrate that European catfish fillets gathered from individuals with a corporal mass around $2000 \mathrm{~g}$, kept their qualitative features for commercialization and consumption for a period of about 12-13 days from the debut of refrigeration in chilled air flow. Sensorial analysis shown the fact that refrigerated European catfish fillets are in according with freshness point of view till day 12 . Obtained values after $\mathrm{pH}$ and $\mathrm{NH}_{3}$ analyzing qualify the analyzed samples as being fresh in the same interval, quite fresh till day 14 and altered at the end of storage period, which is day 16. The obtained data represent a clear indicator of existent correlation between those three methods of evaluation of freshness state of meat products. These results correspond to a meat refrigeration temperature around the value $+2^{\circ} \mathrm{C}$, without any interruption of refrigeration cycle.

Acknowledgments. This paper was published under the frame of European Social Fund, Human Resources Development Operational Programme 2007-2013, projectno. POSDRU/159/1.5/S/132765.

\section{REFERENCES}

1. Alp A, Kara C and HM Buyukcapar (2004). Reproductive biology in a native European catfish, Silurus glanis L. 1758, population in Menzelet Reservoir, Turkish Journal of Veterinary \& Animal Sciences (28): 613-622.

2. Banu C, Gudima Angela, Lungu Cornelia and Rodica Sturza (2004). Biochimie generală şi biochimia peștelui.

3. Banu C, Vizireanu Camelia, Răsmeriță D, Nour Violeta, Musteață G and Silvia Rubțov (2007). Calitatea şi analiza senzorială a produselor alimentare, Ed. Agir, București.

4. Barbara Jankowska, Zdzisław Z, Mijewski T, Ulikowski D and Agata Kowalska (2007). Slaughter value and flesh characteristics of European catfish (Silurus glanis) fed natural and formulated feed under different rearing conditions, Eur. Food Res. Technol., (224): 453-459.

5. Benigno Elvira (2001). Identification of non-native freshwater fishes establised in Europe and assesment of their potential threats to the biological diversity, Strassbourg, Council of Europe.

6. Brzuska E and J Adamak (1999). Artificial spawning of European catfish (Silurus glanis L): Stimulation using LHRH-a ovaprim and carp pituitary extract, Aquae. Res. (30): 59-64.

7. Bud I and V Mireşan (2008). Contributions concerning the quality indices' appreciation in main aquatic organisms, which fall under human consumption, AACL Bioflux (1): 73-83.

8. Ćirković M, Ljubojević D, Đorđević N, Petronijević N, Matekalo-Sverak V and D Trbović (2012). The Breed
Effect on Productivity and Meat Nutrient Compsition of Fish, Kafkas, Univ. Vet. Fak. Derg, 18 (5): 775-780.

9. Connell JJ (1995). Quality deterioration and extrinsic quality defects in raw material, in: Control of Fish Quality, Fishing News Books Ltd. Surrey, England: 31-35.

10. Fauconneau B and M Laroche (1996). Characteristics of the flesh and quality of products of catfishes, Aquat. Living Resour, Vol. 9, Hors série: 165-179.

11. Hallier A, Serot $T$ and C Prost (2007). Influence of rearing conditions and feed on the biochemical composition of fillets of the European catfish (Silurus glanis), Elsevier, Food Chemistry (103): 808-815.

12. Hossain MI, Islam MS, Shikha FH, Kamal M and MN Islam (2005). Physicochemical changes in Thai Pangas (Pangasius sutchi) muscle during ice-storage in an insulated ice box. Pakistan Journal of Biological Sciences, 2005. 8 (6): 798-804.

13. Huss HH (1988). Fresh fish quality and quality changes, a training, FAO Fisheries Series, No. 29, Italy.

14. Huss HH (1995). Quality and quality changes in fresh fish, FAO Fisheries Technical Paper 348, Sub-committee on Fish Trade, Food and Agriculture Organization of the United Nations.

15. Ihuahi JA, Joseph,E and FS Omojowo (2010). Studies on the Post-Mortem Changes in African Catfish (Clarias angullaris) During Ice -Storage, New York Science Journal 3 (6): 96-101.

16. Ionescu Aurelia (2006). Procesarea industrială a peştelui. Ed. Fundației Universitarea Dunărea de Jos, Galați.

17. Iurca IM (2008). Tehnologia cărnii şi subproduse din pește, Ed. ICPIAF, Cluj-Napoca.

18. Kok F, Goksoy E and Z Gonulalan (2009). The microbiological, chemical and sensory features of vacuumed-packed wels Catfish (Silurus glanis L.) pastrami stored under ambient conditions $\left(20^{\circ} \mathrm{C}\right)$, Journal of Animal and Veterinary Advances 8 (4): 817-824.

19. Küçükgülmez A, Eslem Kadak A and C Mehmet (2010). Fatty acid composition and sensory properties of Wels catfish (Silurus glanis) hot smoked with different sawdust materials, International Journal of Food Science and Technology 2010, (45): 2645-2649.

20. Nistor C (2013). Contribuții la cunoașterea calității cărnii de păstrăv crescut în bazine piscicole din Moldova, Teză de doctorat, USAMV Iaşi.

21. Savu C (2008). Igiena şi controlul produselor de origine animală, Ed. Semne, București.

22. Simeanu Cristina (2012). Contribuții la cunoașterea calității cărnii obținută de la specia de sturion Polyodon spatula, Teza de doctorat, USAMV Iaşi.

23. Şindilar E and N Stratan (1996). Expertiza sanitar veterinară a alimentelor de origine animală, Tipografia Centrală, Chișinău.

24. Tekelioğlu N (2005). Iç Su Balıkları Yetistiriciliği, Çukurova Üniversitesi Su Ürünleri Fakültesi Ders Kitabı No-2, Adana, Turkey.

25. Usturoi MG, Păsărin B, Boișteanu PC, Fotea Lenuța (2009). Industrializarea peştelui. Ed. Ion Ionescu de la Brad, Iaşi.

26. ***www.fao.org 